\title{
Antibacterial Activity of Carica papaya Leaves and Allium sativum Cloves Alone and in Combination against Multiple Strains
}

\author{
Srividya Lonkala *, A. Rama Narsimha Reddy
}

\section{Srividya Lonkala *, A.} Rama Narsimha Reddy

Department of Pharmaceutical Sciences, Beside LMD Police Station, Thimmapur, Karimnagar-505481, Telangana, INDIA.

\section{Correspondence}

Dr. Srividya Lonkala, M. Pharm., Ph.D

Associate Professor and HOD, Departmentof Pharma Analysis \& Quality Assurance, Jyothishmathi Institute of Pharmaceutical Sciences, Beside LMD Police Station, Thimmapur, Karimnagar, Telangana, INDIA.

Phone no : +91 9493472098

E-mail: svps11288@gmail.com

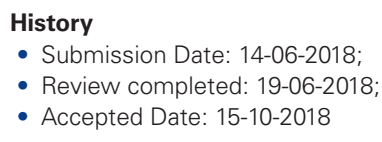

DOI : 10.5530/pj.2019.11.95

Article Available online http://www.phcogj.com/v11/i3

\section{Copyright}

(c) 2019 Pharmacognosy Journal. This is an open-access article distributed under the terms of the Creative Commons Attribution 4.0 International license.

\begin{abstract}
Aim: Screening of natural extracts is a focused intensive study that aims to find active principles sorted from plant resources both safe and environmental friendly. The present study was aimed to evaluate the antibacterial activity of direct crude extracts of Carica papaya leaves and Allium sativum cloves alone and in combination against multiple drug resistant strains. Methods: Two Gram positive (Staphylococcus aureus and Bacillus cereus) and three strains of Gram negative (Escherichia coli, Salmonella typhi and Pseudomonas aeruginosa) bacteria were used to evaluate the antibacterial activity of Carica papaya leaves and Allium sativum using Agar Disk Diffusion Method. Results: The results of this study showed that both extracts showed moderate antibacterial activity against the test bacterial strains and the potency of the extracts was increased when these two extracts were combined. Conclusion: These extracts directly can be used as natural alternative preventives to control various food poisoning diseases and preserve food stuff avoiding healthy hazards of chemically antimicrobial agent applications.

Key words: Carica papaya leaves, Allium sativum cloves, crude extract, Antibacterial activity, Staphylococcus aureus, Bacillus cereus, Escherichia coli, Salmonella typhi, Pseudomonas aeruginosa.
\end{abstract}

\section{INTRODUCTION}

Medicinal plants have become the focus of intense study for potential pharmacological effects. Indeed, the search for new pharmacologically active agents, through the screening of natural sources and plant extracts, has led to the discovery of many clinically useful therapeutic agents that play vital role in the treatment of human diseases. ${ }^{1-2}$ Present day $80 \%$ of individuals from developed countries use traditional medicine, which has compound derived from medicinal plants. Natural products, either as pure compounds or as standardized plant extracts, provide unlimited opportunities for new drug lead molecules due to diverse availability of chemical constituents. ${ }^{3}$ Garlic(Allium sativum, Liliaceac) ${ }^{4}$ and Papaya (Carica papaya, Caricaceae $)^{5}$ has been known for their traditional dietary and medicinal applications as an anti infective agents.

Carica papaya has been used as remedy against a variety of diseases. Carica papaya is a neutraceutical plant having a wide range of pharmacological activities. The whole plant has its own medicinal value. Papaya is a powerhouse of nutrients and is available throughout the year. It is a rich source of threes powerful antioxidant vitamin $\mathrm{C}$, vitamin $\mathrm{A}$ and vitamin $\mathrm{E}$; the minerals, magnesium and potassium; the $B$ vitamin pantothenic acid and folate and fiber. ${ }^{6}$ Leaves have been poulticed into nervous pains, elephantoid growths. ${ }^{7}$ Papaya leaves are made into tea as a treatment for malaria. Antimalarial and antiplasmodial activity has been noted in some preparations of the plant, the leaves of the papaya plants contain chemical compounds of karpain, Substance which kills microorganisms that often interfere with the digestive function. ${ }^{8}$ Papaya leaf extracts have phenolic compounds, such as protocatechuic acid, p-coumaric acid, 5, 7dimethoxycoumarin, caffeic acid, kaempferol, quercetin, chlorogenic acid. ${ }^{9}$ Antifertility, Antihelminthic and anti-inflammatory activity have also been reported. ${ }^{10}$ Papaya leaf has a numberless of benefits and has potential of increasing levels of thrombocytes, leucocytes useful in treating dengue fever. It is found to contain hepatoprotective, gastroprotective activity and boosts up the production of key signaling molecules called Th1-type cytokines for immune protective activity. ${ }^{11}$

Garlic (Allium sativum) is a popular vegetable with a variety of medicinal properties. Garlic bulbs are edible, inexpensive and are readily available traditional dietary and medicinal agent ${ }^{12}$ possesses anti-infective activity. ${ }^{13}$ The fresh and freeze-dried garlic extracts were tested against many bacteria, ${ }^{14-15}$ fungi, ${ }^{16}$ candida $^{17}$ and viruses. ${ }^{18}$ The Garlic Porridge is a kind of herbal diet which lowering blood pres-
Cite this article: Lonkala S, Reddy ARN. Antibacterial Activity of Carica papaya Leaves and Allium sativum Cloves Alone and in Combination against Multiple Strains. Pharmacog J. 2019;11(3):6002. 
Table 1: Yield of extracts.

\begin{tabular}{cccc}
\hline Plant & Part used & Quantity used & extract $(\mathrm{ml})$ \\
\hline Carica papaya & leaf & $250 \mathrm{gm}$ & 12.5 \\
Allium sativum & Cloves & $250 \mathrm{gm}$ & 30.5 \\
\hline
\end{tabular}

Table 2: Antibactarial activity of Carica papaya and Allium sativum alone and in combination.

\begin{tabular}{|c|c|c|c|c|c|}
\hline \multirow{3}{*}{ Plant extract } & \multicolumn{5}{|c|}{ Inhibition zones (mm) } \\
\hline & \multicolumn{2}{|c|}{ Gram(+ve) bacteria } & \multicolumn{3}{|c|}{ Gram (-ve) bacteria } \\
\hline & B. cereus & S. aureus & E. coli & S. typhi & P. aeruginosa \\
\hline Carica papaya & $10.2 \pm 0.27$ & $11.8 \pm 0.21$ & $8.5 \pm 0.5$ & $0.0 \pm 0.0$ & $7.5 \pm 0.62$ \\
\hline Allium sativum & $11.3 \pm 0.57$ & $8.5 \pm 0.18$ & $14.7 \pm 0.16$ & $8.5 \pm 0.21$ & $10.5 \pm 0.64$ \\
\hline Combined extract & $16.2 \pm 0.47$ & $18.6 \pm 0.23$ & $16.2 \pm 0.71$ & $9.2 \pm 0.36$ & $12.8 \pm 0.22$ \\
\hline Gentamycin $(5 \mu \mathrm{g})$ & $18.2 \pm 0.37$ & $21.5 \pm 0.21$ & $18.8 \pm 0.42$ & $17.7 \pm 0.12$ & $15.4 \pm 0.53$ \\
\hline
\end{tabular}

Data are means of three replicates $(n=3)$ Mean \pm SD.

sure and blood lipid, soften blood vessel. The tonic diet for nourishing and moistening the lung, nourish blood and soothing the liver, lower the blood pressure. Taking or eating garlic can benefit cardiovascular health, physical and sexual vitality, cognition and resistance to infection. It also has anti-aging properties. Raw or aged garlic reliably reduces total cholesterol and Low-density Lipoprotein (LDL-C), while increasing Highdensity Lipoprotein (HDL-C). Known traditionally as suitable for those who suffered with health problems of hypertension. Garlic also finds use as Antiprotozoal activity against Entameoba histolytica, anticandidal effects. Cloves are known to possess antimicrobial, anticancer, antioxidant, antidiabetic, antiemetic, antihypertensive, hypoglycemic, hypolipidemic and immunomodulatory. ${ }^{19}$ In the present study, we evaluated the antibacterial activity of direct crude extracts of Carica papaya leaves and Allium sativum cloves alone and in combination against various strains.

\section{MATERIALS AND METHODS}

\section{Plant Extraction}

Fresh, middle stage age, Carica papaya leaves were picked. Leaves were washed and the stems were removed before use. After weighing, leaves were directly blended without adding water or other liquids. Then the mixture was filtered to obtain a crude extract of Carica papaya leaves. Finally, the volume of the extract was measured and used directly for the evaluation. Fresh garlic bulbs were purchased from a retail food store. The outer skin of the garlic cloves was peeled and crushed in a garlic press. The pressed garlic was then collected in a beaker and mixed thoroughly. The pressed mash was filtered to obtain a crude extract of Allium sativum and the volume of the extract was measured and used directly for the evaluation.

\section{Bacterial strains}

The antibacterial potency of each plant extract individually and in combination was evaluated using five bacterial strains causing infections. Two strains of Gram positive (Staphylococcus aureus and Bacillus cereus) and three strains of Gram negative (Escherichia coli, Salmonella typhi and Pseudomonas aeruginosa) bacteria were used.

\section{Antibacterial activity of extracts}

The disk diffusion method ${ }^{20}$ was used to evaluate antibacterial activity of the each plant extract. The extracts were sterilized through Millipore filter of bore $0.22 \mu \mathrm{m}$ and loaded (volume of $0.1 \mathrm{ml} /$ disc of crude extract) on sterile filter paper discs of $10 \mathrm{~mm}$ diameter. Ten $\mathrm{ml}$ of Mueller-Hilton agar medium was poured into sterile Petri dishes as agar followed by addition of $15 \mathrm{ml}$ of seeded medium previously inoculated with bacterial suspension to attain $10^{5} \mathrm{CFU} / \mathrm{ml}$ of medium indicating $100 \mathrm{ml}$ of medium $/ 1 \mathrm{ml}$ of $10^{7} \mathrm{CFU}$. Sterile filter paper discs loaded with plant extract were placed on the top of Mueller-Hilton agar plates. Filter paper discs loaded with $5 \mu \mathrm{g}$ of Gentamycin was used as positive control. The plates were kept in the fridge at $5^{\circ} \mathrm{C}$ for $2 \mathrm{~h}$ to permit plant extracts diffusion, then incubated at $37^{\circ} \mathrm{C}$ for $24 \mathrm{~h}$. The presence of inhibition zones were measured by Vernier caliper recorded and noted for antibacterial activity.

\section{RESULTS AND DISCUSSION}

The yields of extracts of employed plants are illustrated in Table 1.

The plant extracts were investigated to evaluate their antibacterial activity against bacteria including two strains of Gram positive bacteria (B. cereus and S. aureus) and three strains of Gram negative bacteria (E. coli, S. typhi and P. aeruginosa) using disc diffusion method. Evaluation of antibacterial activity of these plant extracts was recorded in Table 2.

The results revealed that Carica papaya leaves extract and Allium sativum cloves extracts were potentially effective in suppressing microbial growth with variable potency. The combination of extracts of both plants was found to be most effective combination in retarding microbial growth of all tested pathogenic bacteria at concentration of $10 \mathrm{mg} /$ disc than individual extracts. Carica papaya was found as inactive against the S. typhi.

\section{CONCLUSION}

Based on the results of the present study, it was found that fresh extracts of Carica papaya leaves and Allium sativum cloves showing good antibacterial activity and was found as synergistic activity when these two extracts were combined. These extracts directly can be used as natural alternative preventives to control various food poisoning diseases and preserve food stuff avoiding healthy hazards of chemically antimicrobial agent applications.

\section{ACKNOWLEDGEMENT}

The authors thank management of Jyothishmathi Institute of Pharmaceutical Sciences and also members of laboratory for aid in preparation of this manuscript.

\section{CONFLICT OF INTEREST}

The authors declare no conflicts of interest. 


\section{ABBREVIATIONS}

B. cereus: Bacillus cereus; S. aureus: Staphylococcus aureus; E. coli: Escherichia coli; S. typhi: Salmonella typhi; P. aeruginosa: Pseudomonas aeruginosa; ${ }^{0} \mathrm{C}$ : Degrees Celsius; +Ve: Positive; -Ve: Negative; hrs: Hours of time; ml: Millilitre; mm: Millimetre; $\mu \mathrm{m}$ : Micrometre; $\mu \mathrm{g}$ : Microgram.

\section{REFERENCES}

1. Yue-Zhongm S. Recent natural products based drug development. A pharmaceutical industry perspective. J Nat Prod. 1988;61(8):1053-71.

2. Leitao SG, Castro O, Fonseea EM, Juliao LS, Tavares ES, Leo RR, et al. Screening of general and south American plantsextracts for antimycobacterial activity by the Alamar Blue test. Rev Bras Farmacogn. 2006;16:6-11.

3. Parekhm PJ, Chandam SV. In vitro Antimicrobial Activity and Phytochemical Analysis of Some Indian Medicinal Plants. Turk J Biol. 2007;31(1):53-8.

4. Lawson LD. Garlic: a review of its medicinal effects and indicated active compounds. Phytomedicines of Europe: chemistry and biological activity. 1998;176-209

5. Alabi OA, Haruna MT, Anokwuru CP, Jegede T, Abia H, Okegbe V, et al. Comparative studies on antimicrobial properties of extracts of fresh and dried leaves of Carica papaya (L) on clinical bacterial and fungal isolates. Pelagia Research Library. 2012;3(5):3107-14.

6. Aravind. G, Debjit B, Duraivel. S, Harish. G. Traditional and Medicinal Uses of Carica papaya. Journal of Medicinal Plants Studies. 2013;1(1):7-15.

7. Asolkar LV, Kakkar KK, Chakre OJ. Glossary of Indian Medicinal Plants with active principles. Part 1 (A-K).Publications by Information Directorate, CSIR New Delhi. 1992;171-3.

8. Udoh P, Essien I, Udoh F. Effect of Carica papaya (paw paw) seeds extract on the morphology of pituitary-gonadal axis of male Wistar rats. Phytother Res. 2005; 19(12):1065-8

9. Romasi EF, Karina J, Parhusip AJN. Antibacterial activity of papaya leaf extracts against pathogenic bacteria. Makara Teknologi. 2011;15(2):173-7.

10. Jyotsna KP, Yashab K. Antibacterial Activity of Seed and Leaf Extract of Carica papaya var. Pusa dwarf Linn. Journal of Pharmacy and Biological Science. 2016;(2):2319-7676

11. Raiyani D, Ansari R. About dengue fever and Carica papaya, a leaf extract of papaya is use to treat dengue fever: a review. Indo American Journal of Pharmaceutical Research. 2016;2231-6876.

12. Eja M, Arikpo G, Enyi-Idoh K, Ikpeme E. An evaluation of the antimicrobial synergy of Garlic (Allium sativum) and Utazi (Gongronema latifolium) on Escherichia coli and Staphylococcus aureus. Malaysian Journal of Microbiology. $2011 ; 7(1): 49-53$

13. Pakdel F, Ghasemi S. Antibacterial Effects of Garlic Extracts and Ziziphora Essential Oil on Bacteria Associated with Peri-Implantitis. Journal of clinical and diagnostic research. 2017;11(4):ZC16-19

14. Cavallito CJ, Bailey JH. Allicin, the antibacterial principle of Allium sativum I. Isolation, physical properties and antibacterial action. J Am Chem Soc. 1944;66(11):1950.

15. Rees LP, Minney SF, Plummer NT, Slater JH, Skyrme DA. A quantitative assessment of the antimicrobial activity of garlic (Allium sativum). World $\mathrm{J}$ Microbiol Biotechno. 1993;9(3):303-7.

16. Adetumbi M, Javor GT, Lau BHS. Allium sativum (Garlic) inhibits lipid synthesis by Candida albicans Antimicrob. Agents Chemother. 1986;30(3):499-501.

17. Katey M, Ourania P, Miguel A, Sonia C, Carsten T, Sue P, et al. Allyl alcohol and garlic (Allium sativum) extract produce oxidative stress in Candida albicans. Microbiology. 2005;151(10):3257-65

18. Weber ND, Anderson DO, North JA, Murray BK, Lawson LD, Hughes BG In vitro virucidal effects of Allium sativum (garlic) extract and compounds. Planta Med. 1992;58(5):417-23.

19. Otunola GA, Afolayan AJ. Characterization, antibacterial and antioxidant properties of silver nanoparticles synthesized from aqueous extracts of Allium sativum, Zingiber officinale and Capsicum frutescens. Pharmacognosy Magazine. 2017;13(2):201-8.

20. Mostafa A, Al-Askar A. Antimicrobial activity of some plant extracts against bacterial strains causing food poisoning diseases. Saudi Journal of Biological Sciences 2017:1319.

\section{ABOUT AUTHORS}

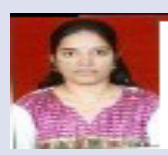

Dr. Srividya Lonkala is an Associate Professor and Head, Department of Pharmaceutical Chemistry at Jyothishmathi Institute of Pharmaceutical Sciences, Karimnagar with over 7 years of professional experience in Pharma Teaching and research. She is $\mathrm{Ph} D$ in Pharmacy from Sunrise University, Alwar, Rajasthan, India. She has authored about 15 research papers covering Ethnopharmacognosy, antiulcer, antidiabetic and anticancer activities.

\section{SUMMARY}

- Virtually plants are natural medicines with active principles serving as effective treatment regimens.

- Subsequently combination of these plant extracts provide additive and beneficiary uses in various aspects of nutrition, antioxidant, wound healing and so on.

- Carica graded as good vitamin supplement and Garlic being powerful immunomodulator their combination is expected to be a better antimicrobial agent.

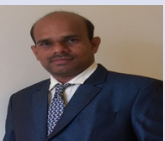

Dr. Anreddy Rama Narsimha Reddy is a Professor and HOD, Department of Pharmacology at Jyothishmathi Institute of Pharmaceutical Sciences, Karimnagar with over 12 years of professional experience in Pharma research. He holds an U.S Patent on Copper Nanoparticles for cancer treatment. He is Ph D in Pharmacology from Kakatiya University College of Pharmacy, Warangal, Telangana, India. He has authored several research papers, research reports covering several areas of Pharmacology, Toxicology, Nano Sciences. He continues to work on research studies in Pharmacology. He has contributed more than 80 papers and 13 books in the areas of Pharmacology and Toxicology.

Cite this article: Lonkala S, Reddy ARN. Total Phenolic, Antibacterial Activity of Carica papaya Leaves and Allium sativum Cloves Alone and in Combination against Multiple Strains. Pharmacog J. 2019;11(3):600-2. 